\title{
THE PELAGIC SHRIMPS (DECAPODA, NATANTIA) OF THE AEGEAN SEA, WITH AN ACCOUNT OF THE MEDITERRANEAN SPECIES
}

\author{
BY
}

\section{A. KOUKOURAS}

Department of Zoology, Aristoteleio University of Thessaloniki, GR-540 06 Thessaloniki, Greece

\begin{abstract}
Recent sampling carried out in the Aegean with the use of a mid-water trawl, yielded 12 species of pelagic shrimps, 6 of which (Acanthephyra eximia, A. pelagica, Pasiphaea multidentata, Sergestes arcticus, $S$. atlanticus, and $S$. sargassi) are reported for the first time from the Aegean. For all the above species as well as for 6 other so far known from the Mediterranean, information is given on their distribution in certain geographical areas of the Mediterranean and the adjacent oceans.
\end{abstract}

\section{RÉSUMÉ}

Des échantillonnagesrécents effectués en mer Egée, à l'aide d'une chalut de demiprofondeur, ont fourni 12 espèces de crevettes pélagiques, dont six (Acanthephyra eximia, A. pelagica, Pasiphaea multidentata, Sergestes arcticus, $S$. atlanticus, et $S$. sargassi) sont signalées pour la première fois en mer Egée. Pour toutes les espèces ci-dessus comme pour six autres connues jusqu'à présent de Méditerranée, des informations sont données sur leur répartition dans les différentes aires géographiques de cette mer et des océans voisins.

\section{INTRODUCTION}

A review of the relevant literature shows that the Mediterranean pelagic shrimps are poorly known, especially the genera Sergestes and Sergia. Most records of these species from the various Mediterranean areas are based on a small number of adult individuals or larval stages, the identification of which was problematic because of the confused descriptions of these species. As a result, these records are in part doubtful. Most problems were elucidated after the review by Crosnier \& Forest (1973) and later after those by Vereshchaka (1994) and Pérez Farfante \& Kensley (1997). However, the absence of Mediterranean material in these papers leaves certain records from the Mediterranean still uncertain.

Koukouras et al. (1992), listing the decapod fauna of the Aegean Sea, pointed out the lack of information concerning the pelagic shrimps. The limited information existing on the pelagic shrimps of the Aegean (including the Sea of Marmara) 
is included in older papers, i.e., those of Guérin (1832), König (1895), Ostroumoff (1896), Adensamer (1898), and Stephensen (1923), and in the more recent ones by Drensky (1951), Bacescu \& Mayer (1961), Vamvakas (1970), Koukouras \& Kattoulas (1974), Kaspiris (1990), and Koukouras et al. (1992), which report the presence of a total of 7 species from this area. The record of Acanthephyra purpurea A. Milne-Edwards, 1881 (possibly A. pelagica (Risso, 1816)) by Katagan et al. (1988) from the SW coast of Turkey should be considered an erroneous identification.

\section{MATERIAL AND METHODS}

In the framework of a broader study of the pelagic fauna in the northern Aegean Sea, one fishing cruise was performed in summer 1993, from 17 to 28 July. A grid of 9 stations (fig. 1) was designed, all over the study area. At each station, samples were taken at depths of 250, 500, 750, and $1000 \mathrm{~m}$, during daytime. A METHOD mid-water trawl with a mouth aperture of $2.2 \mathrm{~m}$, fitted with a net of $3.0 \mathrm{~mm}$ mesh at the cod end, was used for sampling. Next to the decapod samples from the above tows, some additional specimens of pelagic shrimps, which were collected from six other areas of the Aegean Sea (off the SW coast of Chios Island, station 10; off the SE coast of Athos Peninsula, sta. 11; north Evoikos Gulf, sta. 12; off the north coast of Crete, sta. 13; off Crete, $35^{\circ} 54^{\prime} 96^{\prime \prime} \mathrm{N} 25^{\circ} 10^{\prime} 04^{\prime \prime} \mathrm{E}$, sta. 14; and off the SW coast of Simi Island, sta. 15) were also examined.

\section{RESULTS}

Examination of the material collected gave new information concerning various pelagic shrimps of the Aegean Sea. The abbreviation $\mathrm{Cl}=$ carapace length: measured from the posterior margin of the orbit to the terminal border of the carapace.

\section{OPLOPHORIDAE}

\section{Acanthephyra eximia Smith, 1884}

Acanthephyra eximia. - Crosnier \& Forest, 1973: 34, fig. 7c-d.

Material examined. - 5 juv., sta. 4, depth $250 \mathrm{~m}$, water column; 2 juv., sta. 7, depth $500 \mathrm{~m}$, water column; $24 \sigma^{7} \sigma^{7}, 13$ 우, sta. 14, depth $1830 \mathrm{~m}$, silty substratum, 18.i.1998, baited traps. Max. Cl $\sigma^{7}$ $=32.0 \mathrm{~mm} ; \max . \mathrm{Cl}$ $=32.0 \mathrm{~mm}$.

This nektobenthic (Chace, 1940; Cartes, 1993) species has been reported in this area only off the western $\left(35^{\circ} 36^{\prime} \mathrm{N} 23^{\circ} 18^{\prime} \mathrm{E}\right)$ and southern coast $\left(34^{\circ} 45^{\prime} \mathrm{N} 24^{\circ} 23^{\prime} \mathrm{E}\right.$; 


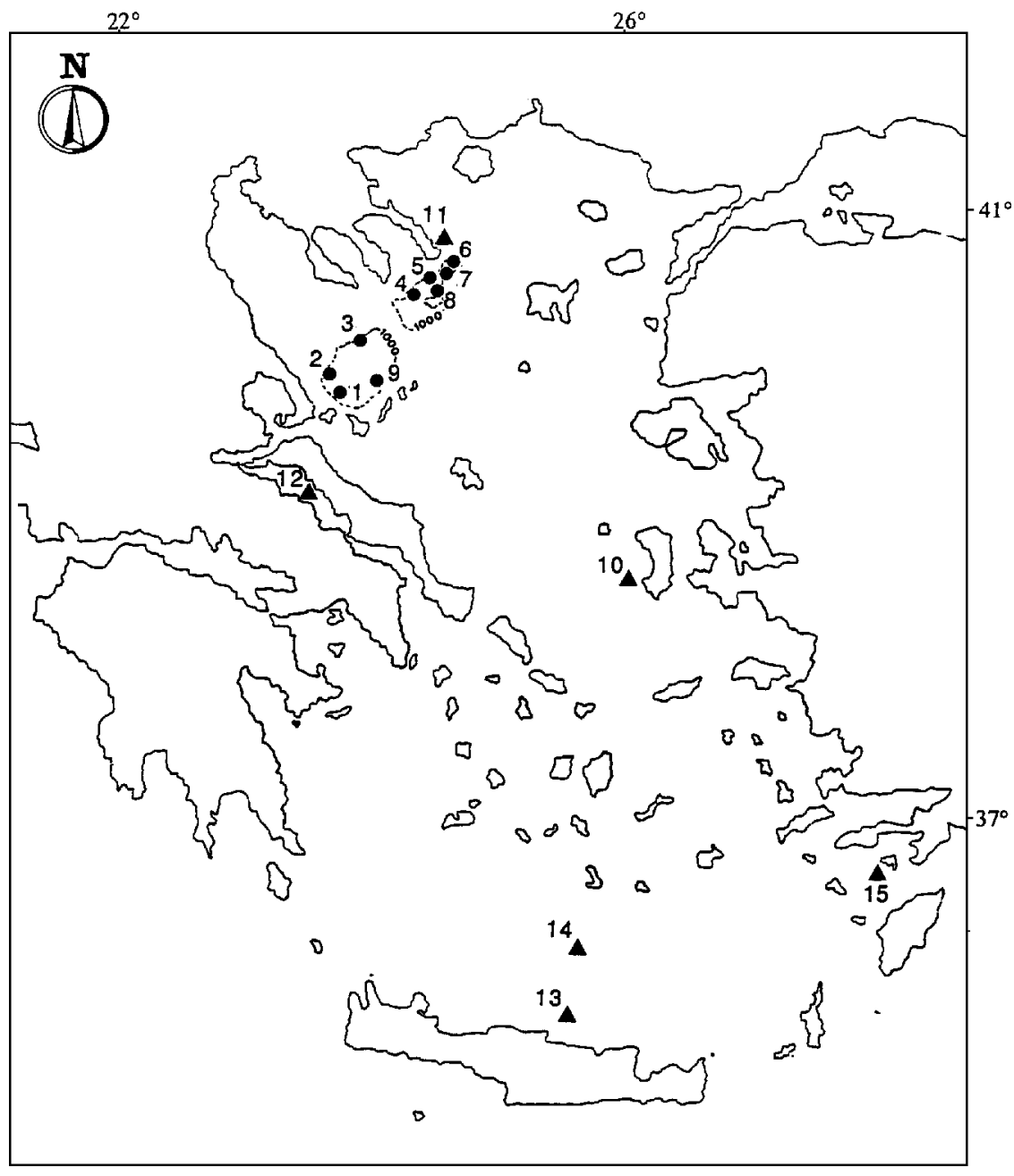

Fig. 1. Map of the Aegean Sea, indicating the sampling stations.

$33^{\circ} 4^{\prime} \mathrm{N} 24^{\circ} 17^{\prime} \mathrm{E}$ ) of Crete (Adensamer, 1898, as A. pulchra A. Milne-Edwards, 1890). Thus, its presence in the Aegean is here reported for the first time.

This cosmopolitan species (Crosnier \& Forest, 1973) has been known in the Mediterranean (table I) from the western basin (e.g., Zariquiey Alvarez, 1968), the central Mediterranean (e.g., Adensamer, 1898), and the Levantine Basin (e.g., Galil \& Goren, 1994).

Acanthephyra pelagica (Risso, 1816)

Acanthephyra pelagica. — Sivertsen \& Holthuis, 1956: 7, figs. 3-7. 
Material examined. - 21 juv., $10 \sigma^{7} \sigma^{7}, 4$ \$९, sta. 1, depths 750 and $1000 \mathrm{~m}$, water column; 42 juv., $9 \sigma^{7} \sigma^{7}, 3$ \&o, sta. 2, depths 750 and $1000 \mathrm{~m}$, water column; 54 juv., $2 \sigma^{7} \sigma^{7}$, sta. 3, depth $750 \mathrm{~m}$, water column; 10 juv., $6 \sigma^{7} \sigma^{7}, 2$ o, , sta. 4, depth 750 m, water column; 11 juv., $6 \sigma^{7} \sigma^{7}, 1$ ovig , sta. 5 , depth $500 \mathrm{~m}$, water column; 32 juv., $1 \sigma^{7}$, sta. 6 , depth $750 \mathrm{~m}$, water column; 33 juv., $4 \sigma^{7} \sigma^{7}, 2$ o sta. 7, depth $750 \mathrm{~m}$, water column; 18 juv., $3 \sigma^{7} \sigma^{7}$, sta. 8, depths 750 and $1000 \mathrm{~m}$, water column; 12 juv., $3 \sigma^{7} \sigma^{7}, 3$ oᄋ, sta. 9, depths 750 and $1000 \mathrm{~m}$, water column; $1 \sigma^{7}$, sta. 13, in the stomach of the fish Nettastoma melanurum Rafinesque, 1810, fished at a depth of 850 m, 15.v.1994. Max. Cl ơ = $22.0 \mathrm{~mm}$; max. $\mathrm{Cl}$ \% (ovig.) $=19.5 \mathrm{~mm}$.

This bathypelagic shrimp was known in this area only from off the SE coast of Rodos Island (Stephensen, 1923; as A. multispina Coutière, 1905) and SE of Crete (Christiansen, 1989). Consequently, it is now reported for the first time from the Aegean.

An amphi-Atlantic species (Crosnier \& Forest, 1973), known in the Mediterranean (table I) from the western basin (e.g., Sardá \& Palomera, 1981), the central Mediterranean (Stephensen, 1923, as A. multispina), the Adriatic (Froglia \& Giannini, 1984), and the Levantine Basin (Stephensen, 1923; Christiansen, 1989; Galil \& Goren, 1994).

\section{PASIPHAEIDAE}

\section{Pasiphaea multidentata Esmark, 1866}

Pasiphaea multidentata. — Zariquiey Alvarez, 1957: 16, figs. 5-6, pls. 4-9.

Material examined. - 4 juv., sta. 1, depth 750 m, water column; 9 juv., $2 \sigma^{7} \sigma^{7}$, sta. 2, depths 500, 750 and $1000 \mathrm{~m}$, water column; 6 juv., sta. 4, depths 500 and $750 \mathrm{~m}$, water column; 2 juv., sta. 5, depths 500 and $1000 \mathrm{~m}$, water column; 2 juv., sta. 6, depth $750 \mathrm{~m}$, water column; 2 juv., sta. 7, depth $750 \mathrm{~m}$, water column; 2 juv., sta. 9 , depths 750 and $1000 \mathrm{~m}$, water column. Max. $\mathrm{Cl} \sigma^{7}=30.6 \mathrm{~mm}$.

Remark. - Figueira (1957) first observed that the numbers of spines on the ventral margin of the merus of the first and second pereopods and on the ventral margin of the basis of the second pereopod increase with age. In the specimens examined, the number of spines on the ventral margins of the basis and merus of the second pereopods increased with carapace length as follows: $\mathrm{Cl}=6.0 \mathrm{~mm}$, $1+0 ; \mathrm{Cl}=8.5 \mathrm{~mm}, 3+1 ; \mathrm{Cl}=10.5 \mathrm{~mm}, 5+2 ; \mathrm{Cl}=14.5 \mathrm{~mm}, 8+2 ; \mathrm{Cl}=30.6 \mathrm{~mm}$, $17+2$. In Iwasaki's (1990) collection, the largest specimen $(\mathrm{Cl}=35.2 \mathrm{~mm})$ had 12-13 spines on the basis of the second pair of pereopods and 25-28 on the merus of the second pair. Consequently, it is obvious that the number of spines increases with age but that in large individuals these numbers may vary substantially.

The bathypelagic $P$. multidentata has been reported in this area only off the SE coast of Rodos (Stephensen, 1923). Its presence in the Aegean is now reported for the first time. 
An amphi-Atlantic species (Sivertsen \& Holthuis, 1956; Burukovskii, 1976) known in the Mediterranean (table I) from several areas of the western basin (e.g., Stephensen, 1923; Zariquiey Alvarez, 1968), the central Mediterranean (e.g., Arena \& Li Greci, 1973; Pipitone \& Tubiolo, 1993), the Adriatic (e.g., Pesta, 1918; Froglia \& Giannini, 1984), and the Levantine Basin (Stephensen, 1923; Galil \& Goren, 1994).

\section{Pasiphaea sivado (Risso, 1816)}

Pasiphaea sivado. —Zariquiey Alvarez, 1968: 70, figs. 6a, 30.

Material examined. $-3 \sigma^{7} \sigma^{7}, 1$ ovig. $q(\mathrm{Cl}=20.1 \mathrm{~mm}$, bearing 63 eggs, diameter $=1.2 \mathrm{~mm})$, sta. 1, depth $500 \mathrm{~m}$, water column; 1 juv., sta. 7, depth $500 \mathrm{~m}$, water column; $1 \sigma^{\text {r }}$, sta. 10, depth $500 \mathrm{~m}$, water column, 16.v.1997; $1 \sigma^{7}$, sta. 11, depth $400 \mathrm{~m}$, water column, 14.vi.1995; $11 \sigma^{7} \sigma^{7}$, 9 우 ( 2 ovig.: $\mathrm{Cl}=17.2 \mathrm{~mm}$, with 55 eyed eggs, diameter $=1.5 \mathrm{~mm}$; and $\mathrm{Cl}=21.2 \mathrm{~mm}$, with 88 eyed eggs, diameter $=1.8 \mathrm{~mm}$ ), sta. 12 , depth 100-400 m, water column, 10.xii.1993. Max. $\mathrm{Cl} \sigma^{7}=$ $25.2 \mathrm{~mm}$; max. $\mathrm{Cl} q=21.2 \mathrm{~mm}$.

Remark. - There are ovigerous females of the species throughout the year (Zariquiey Alvarez, 1968; Froglia \& Giannini, 1984; Pipitone \& Tubiolo, 1993).

This pelagic species was known in the Aegean from: Sapientza (Kithyra) Island, the coast of Peloponnisos, Naxos Island (Guérin, 1832); Korinthiakos Gulf, the Sporades Islands, the Sea of Marmara (Stephensen, 1923); Thasos Island (Drensky, 1951); Evoikos Gulf (Koukouras \& Kattoulas, 1974); Saronikos Gulf (Vamvakas, 1970); Korinthiakos Gulf (Kaspiris, 1990).

An Atlanto-Mediterranean species (Kensley, 1981; Iwasaki, 1990) known in the Mediterranean (table I) from several areas of the western basin (e.g., Heller, 1863; Zariquiey Alvarez, 1957; Relini Orsi, 1974), the central Mediterranean (Arena \& Li Greci, 1973; Pipitone \& Tubiolo, 1993), the Adriatic (e.g., Pesta, 1918; Froglia, 1972; Bombace \& Froglia, 1973), and the Levantine Basin (Galil \& Goren, 1994).

\section{BENTHESICYMIDAE}

Gennadas elegans (Smith, 1882)

Amalopenaeus elegans Smith, 1882: 87, pl. 14 figs. 8-14, pl. 15 figs. 1-5. Gennadas elegans. — Bouvier, 1908: 35, pl. 7 figs. 1-24.

Material examined. - 681 juv., $140 \sigma^{7} \sigma^{7}, 85$ $\subsetneq$, stas. 1-9, depths 250, 500, 750 and $1000 \mathrm{~m}$, water column; $6 \sigma^{7} \sigma^{7}, 4$ 우, sta. 11, depth $500 \mathrm{~m}$, water column, 14.vi.1995. Max. $\mathrm{Cl} \sigma^{7}=9.5 \mathrm{~mm}$; $\max . \mathrm{Cl} q=10.5 \mathrm{~mm}$.

This bathypelagic species, was known in the Aegean only from the Sea of Marmara, $4^{\circ} 48^{\prime} \mathrm{N} 27^{\circ} 59^{\prime} \mathrm{E}$; the Gulf of Korinthos, $38^{\circ} 10^{\prime} \mathrm{N} 22^{\circ} 33^{\prime} \mathrm{E}$; and the Sporades Islands, $37^{\circ} 52^{\prime} \mathrm{N} 26^{\circ} 22^{\prime} \mathrm{E}$ (Stephensen, 1923). 
An amphi-Atlantic species (Pérez Farfante \& Kensley, 1997) known all over the Mediterranean (table I) (e.g., Pesta, 1918; Stephensen, 1923; Forest, 1965; Zariquiey Alvarez, 1968).

\section{SERGESTIDAE}

\section{Sergestes arachnipodus (Cocco, 1832)}

Sergestes corniculum. - Köning, 1895: 13, pl. 2 fig. 12, pl. 3 fig. 15, pl. 5 fig. 24.

Sergestes rubroguttatus. - Pesta, 1918: 54, fig. 15.

Sergestes(Sergestes) henseni. - Crosnier \& Forest, 1973: 310, figs. 105a-c, 106a, b, e.

Material examined. - 1 \%, sta. 10, depth 300 m, water column, 16.v.1997; 1 \%, sta. 11, depth $500 \mathrm{~m}$, water column, 14.vi.1995. Max. $\mathrm{Cl} \sigma^{7}=8.2$ and $q=13.5 \mathrm{~mm}$.

This pelagic species was known in the Aegean only from the southern part, by the presence of a juvenile individual (Bacescu \& Mayer, 1961; as S. corniculum Krłyer, 1855), and the Sea of Marmara (Ostroumoff, 1896, as Sergestes arachnipodus De Natale, 1850).

An amphi-Atlantic species (D'Udekem d'Acoz, 1999) known from certain areas all over the Mediterranean (table I) under the names S. arachnipodus (Cocco, 1832), S. corniculum Krłyer, 1855, S. rubroguttatus Wood Mason, 1891, and S. henseni (Ortmann, 1893) (e.g., Senna, 1902; Lo Bianco, 1903; Pesta, 1918; Hansen, 1922; Sardá \& Palomera, 1981; Vaso \& Gjiknuri, 1993; Galil \& Goren, 1994).

\section{Sergestes arcticus Krłyer, 1855}

Sergestes arcticus. — Krłyer, 1859: 240, 276, 285, pl. 3 fig. 7a-g, pl. 5 fig. 16. - Hansen, 1922: 62, pl. 1 figs. 1-2, pl. 3 figs. 3-5, pl. 4 fig. 1.

Material examined. - 163 juv., $460 \sigma^{\top} \sigma^{\top}, 303$ , stas. 1-9, depths 250, 500, 750 and $1000 \mathrm{~m}$, water column; 3 q , sta. 13, depth $500 \mathrm{~m}$, water column, 15.v.1994. $\mathrm{Max} . \mathrm{Cl} \sigma^{7}=14.0 \mathrm{~mm}$; max. $q \mathrm{Cl}$ \% $=14.5 \mathrm{~mm}$ (o, sta. 1 , depth $750 \mathrm{~m}$ ).

Remark. $-1 \%$ of the individuals collected did not bear any supra-orbital spine and $0.5 \%$ had such a spine on one side only.

This is a bathypelagic species reported from the Aegean for the first time here.

A cosmopolitan species (Pérez Farfante \& Kensley, 1997) known in the Mediterranean (table I) from several areas of the western basin (e.g., García Raso, 1982), the central Mediterranean (e.g., Arena \& Li Greci, 1973) and the Adriatic (e.g., Pesta, 1918; Froglia \& Giannini, 1984). 


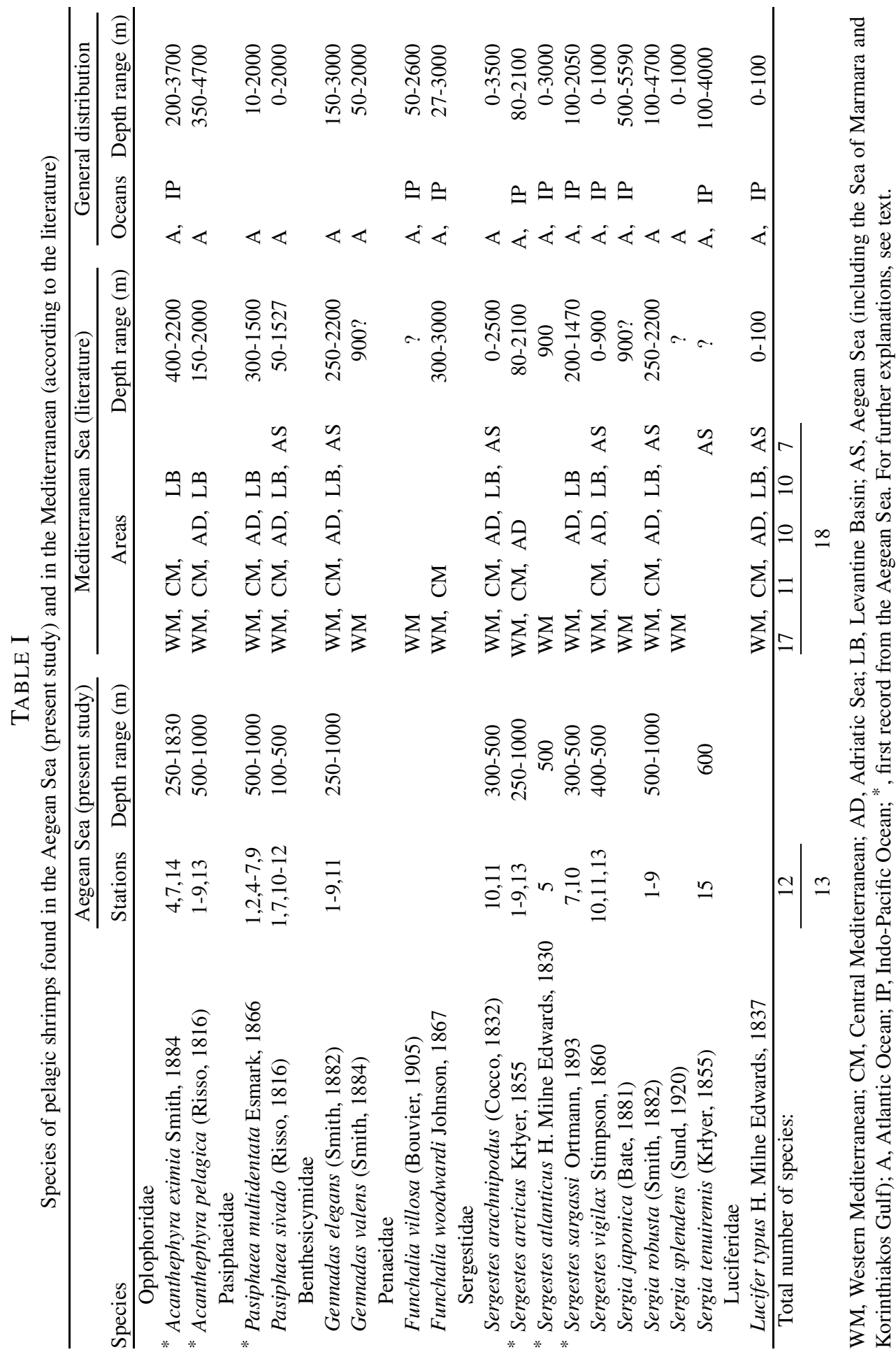




\section{Sergestes atlanticus H. Milne Edwards, 1830}

Sergestes atlanticus. - Bate, 1888: 389, pls. 68-69. — Pérez Farfante \& Kensley, 1997: 196, figs. 137-139.

Material examined. -1 o, sta. 5 , depth $500 \mathrm{~m}$, water column. $\mathrm{Cl}=9 \mathrm{~mm}$.

A bathypelagic species reported here for the first time from the Aegean.

A cosmopolitan species (Pérez Farfante \& Kensley, 1997), so far known in the Mediterranean (table I) only from the western basin, near Gibraltar (Sund, 1920). Seridji (1971) recorded the occurrence of larvae in the Bay of Algiers, at depths between 40 and $80 \mathrm{~m}$ during January, March, and October till December, and Carli \& Pessani (1973) found larvae near the water surface in the western coast of Sicily. Thus, the discovery of this species in the Aegean Sea, constitutes the second record of an adult, for the Mediterranean. This species should be considered very rare in the Mediterranean, given that Foxton (1970) in his extensive samplings in the NE Atlantic only found one individual. It seems to be much more abundant in the Gulf of Mexico (Flock \& Hopkins, 1992).

\section{Sergestes sargassi Ortmann, 1893}

Sergestes (Sergestes) sargassi. — Kensley, 1971: 241, fig. 14.

Material examined. - 1 \%, sta. 7, depth 500 m, water column; 2 oo, 1 ๙ , sta. 10, depth $300 \mathrm{~m}$, water column, 16.v.1997. $\mathrm{Max} . \mathrm{Cl} \sigma^{\gamma}=8.1 \mathrm{~mm} ; \max . \mathrm{Cl} q=10.0 \mathrm{~mm}$.

This bathypelagic species is reported for the first time from the Aegean Sea.

A cosmopolitan species (Pérez Farfante \& Kensley, 1997) known in the Mediterranean (table I) from the western basin (e.g., Hansen, 1922; Cartes et al., 1993), the Adriatic (Froglia \& Giannini, 1984), and the Levantine Basin (Galil \& Goren, 1994).

\section{Sergestes vigilax Stimpson, 1860}

Sergestes vigilax. — Hansen, 1922: 159, pl. 1 fig. 8, pl. 9 fig. 4a-m, pl. 10 fig. 1a-c.

Material examined. - $1 \sigma^{7}$, sta. 10, depth 400 m, water column, 16.v.1997; 4 qo, sta. 11, depth $500 \mathrm{~m}$, water column, 14.vi.1995; 2 фo, sta. 13, depth $400 \mathrm{~m}$, water column, 15.v.1994. Max. Cl ơ $=8.2 \mathrm{~mm}$; $\max . \mathrm{Cl}$ $=11.6 \mathrm{~mm}$.

This bathypelagic species has been reported from the southern Aegean Sea (König, 1895, as Sergia clausi König, 1895, and as Sergestes oculatus Krłyer, $1855)$.

A cosmopolitan species (Pérez Farfante \& Kensley, 1997) known in the Mediterranean (table I) from certain areas of the western basin (e.g., Hansen, 1922; 
Zariquiey Alvarez, 1946), the Adriatic (Pesta, 1918; Froglia \& Giannini, 1984), and certain areas of the central Mediterranean and the Levantine Basin (König, 1895, as Sergia clausi König, 1895, and as Sergestes oculatus Krłyer, 1859).

\section{Sergia robusta (Smith, 1882)}

Sergestes robustus Smith, 1882: 97, pl. 16 figs. 5-8b.

Sergia robusta. - Pérez Farfante \& Kensley, 1997: 200, figs. 140-141.

Material examined. - 234 juv., $40 \sigma^{7} \sigma^{7}, 9$ oक, stas. 1-9, depths 500, 700, and $1000 \mathrm{~m}$, water column. Max. $\mathrm{Cl} \sigma^{\top}=19.5 \mathrm{~mm}$; max. $\mathrm{Cl} \uparrow=20.5 \mathrm{~mm}$ ( 2 females at depths of 500 and $\left.1000 \mathrm{~m}\right)$.

A bathypelagic species known in the Aegean only from its southern part (Bacescu \& Mayer, 1961; Kaspiris, 1990).

An amphi-Atlantic species (Vereshchaka, 1994) known in the Mediterranean (table I) from several areas of the western basin (e.g., Lo Bianco, 1903; García Raso, 1982), the central Mediterranean (Arena \& Li Greci, 1973), the Adriatic (e.g., Pesta, 1918; Pipitone \& Tumbiolo, 1992), and the Levantine Basin (e.g., Adensamer, 1898; Galil \& Goren, 1994).

\section{Sergia tenuiremis (Krłyer, 1855)}

Sergestes tenuiremis. — Illig, 1927: 283, figs. 6-10.

Sergestes krlyeri . - Illig, 1927: 289, figs. 18-25.

Material examined. -1 \%, sta. 15, depth $600 \mathrm{~m}$, water column, 6.x.1997. $\mathrm{Cl}=9.2 \mathrm{~mm}$.

The only previous records of the species in the Mediterranean is that by Ostroumoff (1896) from the eastern basin of the Sea of Marmara (table I), (which was indirectly questioned by Holthuis \& Gottlieb (1958) reporting that Hansen (1922) does not mention this species from the Mediterranean) and that by Müller (1986), also from the Sea of Marmara.

This cosmopolitan, rare and deep-living species occurs throughout tropical and temperate zones of all oceans (Vereshchaka, 1994).

OTHER PELAGIC SHRIMPS FROM THE AEGEAN AND THE MEDITERRANEAN SEA

\section{BENTHESICYMIDAE}

Gennadas valens (Smith, 1884) (table I). This amphi-Atlantic species (Pérez Farfante \& Kensley, 1997) is known in the Mediterranean only from the Alboran Sea, near Gibraltar (Sund, 1920). 


\section{PENAEIDAE}

Funchalia villosa (Bouvier, 1905) (table I). A bathypelagic, cosmopolitan species (Pérez Farfante \& Kensley, 1997) known in the Mediterranean only from certain areas of the western basin (Grippa, 1987).

Funchalia woodwardi Johnson, 1867 (table I). A bathypelagic cosmopolitan species (Pérez Farfante \& Kensley, 1997), known in the Mediterranean only from the central part, near Messina (Grippa, 1976), and certain areas of the western basin (Stephensen, 1923; Zariquiey Alvarez, 1968; Relini-Orsi \& Costa, 1975; Grippa, 1987).

\section{SERGESTIDAE}

Sergia japonica (Bate, 1881) (table I). Bathypelagic cosmopolitan species (Vereshchaka, 1994; Pérez Farfante \& Kensley, 1997), known in the Mediterranean only from the western basin, near Gibraltar (Sund, 1920; as Sergestes mollis Smith, 1882).

Sergia splendens (Sund, 1920) (table I). A mesopelagic amphi-Atlantic species (Vereshchaka, 1994; Pérez Farfante \& Kensley, 1997), known in the Mediterranean only from the western basin, off Monaco (Hansen, 1922, as Sergestes crassus: Synonymized by Hansen, 1922; Kensley, 1971).

\section{LUCIFERIDAE}

Lucifer typus $\mathrm{H}$. Milne Edwards, 1837 (table I). An epipelagic cosmopolitan species (Pérez Farfante \& Kensley, 1997), known all over the western Mediterranean (e.g., Hansen, 1922; García Raso, 1982), the central Mediterranean (Hansen, 1922; Bacescu \& Mayer, 1961), the Adriatic (e.g., Pesta, 1918; Froglia \& Giannini, 1984), the Levantine Basin (e.g., Adensamer, 1898; Holthuis \& Gottlieb, 1958), and the Aegean Sea, between Chalkidiki Peninsula and Limnos Island (Adensamer, 1898, as Leucifer Reynaudii).

\section{DISCUSSION}

As shown in table I, the presence of 18 pelagic species, including the nektobenthic species Acanthephyra eximia, has been reported from the Mediterranean.

None of these species has been recorded from the Black Sea due to the special conditions (mainly the reduced salinity) prevailing there (Caspers, 1957). Seventeen species $(94.5 \%$ ) are known from the western basin of the Mediterranean, which is due to the fact that the invasion of the Atlantic species is initially limited to this basin, and also due to the more intensive sampling carried out in that area. 
Eleven species $(61.1 \%)$ are known from the central Mediterranean, mainly due to the restricted sampling effort in this area. Ten species (55.5\%) have been reported from the Adriatic, possibly because of its significantly restricted communication with the western basin (Ovchinnikov, 1966) and of its shallow waters. Only 10 species $(55.5 \%)$ have been reported from the Levantine Basin, possibly because of its impoverished fauna (Por \& Dimentman, 1989) and of the reduced sampling effort. Thirteen species (72.2\%) have been reported from the Aegean $(7$ of them were previously known, while 6 are recorded for the first time in the present study), possibly due to the more direct communication with the western basin (e.g., Ovchinnikov, 1996) and to the increased sampling effort in this area.

According to the relevant literature, 10 out of the 18 Mediterranean species (55.5\%), are cosmopolitan, since they are distributed both in the Atlantic and in the Indo-Pacific (table I). The remaining 8 (44.5\%) have an Atlanto-Mediterranean distribution.

\section{REFERENCES}

Adens Amer, T., 1898. Decapoden gesammelt auf S. M. Schiff "Pola" in den Jahren 1890-1894. Berichte der Commission für Erforschung des östlichen Mittelmeeres. XXII. Zoologische Ergebnisse. XI. Denkschr. Akad. Wiss. Wien, 65: 597-628.

Arena, P. \& F. Li Gregi, 1973. Indagine sulle condizioni faunistiche e sui rendimenti di pesca dei fondali batiali della Sicilia occidentale e della bordura settentrionale dei banchi della soglia Siculo - Tunisina. Quad. Lab. Tecnol. Pesca, 1 (5): 157-201.

Bacescu, M. \& R. MaYer, 1961. Malacostracés (Mysidacea, Euphausiacea, Decapoda, Stomatopoda) du plancton diurne de la Méditerranée. Etude basée sur le matériel du Lamont Geological Observatory, Washington. Rapp. Comm. int. Mer Méditerranée, 16 (2): 183-202.

Bate, C. S., 1888. Report on the Crustacea Macrura collected by H. M. S. "Challenger" during the years 1873-76. Rep. Voy. Challenger, (Zool.) 24: i-xc, 1-942.

Bombace, G. \& C. Froglia, 1973. Premières remarques sur les peuplements de l'étage bathyal de Basse Adriatique. Rapp. Comm. int. Mer Méditerranée, 22 (4): 93-94.

Bouvier, E. L., 1908. Crustacés Décapodes (Pénéides) provenant des campagnes de l'Hirondelle et de la Princesse Alice (1886-1907). Résultats des Campagnes scientifiques accomplies par le Prince Albert I de Monaco, 33: 1-112, pls. 1-16.

Burukovskit, R. N., 1976. A new species of shrimp, Pasiphaea grandicula sp. n. (Decapoda, Crustacea) and a short outline of the genus' species. Biol. Morya, 4: 17-28.

Carli, A. \& D. Pessani, 1973. Studio delle larvae di Crostacei Decapodi (Natantia e Reptantia) raccolte durante la campagna di pesca del Giugno 1968 alle Isole Egadi (Sicilia). Boll. Pesca Piscic. Idrobiol., 28 (2): 319-329.

CARTES, J. E., 1993. Day-night feeding by decapod crustaceans in a deep-water bottom community in the western Mediterranean. Journ. mar. biol. Assoc. U.K., 73: 795-811.

CARTes, J. E., E. SARdÁ \& P. ABello, 1993. Decapod crustaceans collected by deep-water trawls (between 1000 and $2200 \mathrm{~m}$ ) in the Catalan Area (North-Western Mediterranean). Bios, 1 (1): 206-221.

Caspers, H., 1957. Black Sea and Sea of Azov. Geol. Soc. America Mem., 67 (1): 801-890.

Chace, F. A., 1940. The bathypelagic caridean Crustacea. Plankton of the Bermuda Oceanographic Expedition. IX. Zoologica, New York, 25 (11): 117-209. 
Christiansen, B., 1989. Acanthephyra sp. (Crustacea: Decapoda) in the eastern Mediterranean Sea captured by baited traps. Senckenbergiana marit., 20 (5/6): 187-193.

Crosnier, A. \& J. Forest, 1973. Les crevettes profondes de l'Atlantique oriental tropical. Faune tropicale, 19: 1-409. (O.R.S.T.O.M., Paris).

Drensky, P., 1951. Über Entomostraca und Malacostraca (Cr.) aus dem Agäischen Meer. Ann. Univ. Sofia, (Biol.) 46 (3): 235-250.

FigueiRA, A. J. G., 1957. Madeiran decapod crustaceans in the collection of the Museum Municipal do Funchal. I. On some interesting deep-sea prawns of the families Pasiphaeidae, Oplophoridae and Pandalidae. Bol. Mus. municipal Funchal, 10 (26): 22-51.

FLOCK, M. E. \& T. L. HoPKINS, 1992. Species composition, vertical distribution, and food habits of the sergestid shrimp assemblage in the eastern Gulf of Mexico. Journ. Crust. Biol., 12 (2): 210-223.

Forest, J., 1965. Campagnes du "Professeur Lacaze-Duthiers" aux Baléares: Juin 1953 et Aoßt 1954. Crustacés Décapodes. Vie Milieu, 16 (1-B): 325-413.

FoxTON, P., 1970. The vertical distribution of pelagic decapods (Crustacea Natantia) collected on the Sond cruise 1965. II. The Penaeidea and general discussion. Journ. mar. biol. Assoc. U.K., 50: $961-1000$.

Froglia, C., 1972. Preliminary report on the Crustacea Decapoda of Adriatic deep waters. Thalassia Jugoslavica, 8 (1): 75-79.

Froglia, C. \& S. Giannini, 1984. Pelagic shrimps of the Adriatic Sea. Atti Soc. Italiana Sci. nat. Museo civ. Stor. nat. Milano, 125 (1-2): 49-60.

Galil, B. S. \& M. Goren, 1994. The deep sea Levantine fauna. New records and rare occurrences. Senckenbergiana marit., 25 (1/3): 41-52.

García RAso, J. E., 1982. Penaeidea y Caridea de las costas de Malaga (Region Sur-Mediterranea Esparola). Graellsia,38: 85-115.

GRIPPA, G., 1976. Funchalia woodwardi Johnson, 1867 nelle acque di Sicilia, con osservazioni sul genere. Atti Soc. Italiana Sci. nat. Museo civ. Stor. nat. Milano, 117 (3-4): 117-136, pl. 6.

_ - 1987. A revision of gen. Pelagopenaeus Burkenroad, 1934 and Funchalia Johnson, 1867 (Crustacea, Decapoda, Penaeidea). Inv. Pesq., Barcelona, 51 (Suppl. 1): 73-85.

Guérin-Méneville, F. E., 1832. Ire Classe. Crustacés. In: A. Brullé, Des animaux articulés. Expédition scientifique de Morée. Section des sciences physiques, 3 (1), (Zool.) (2): 30-50.

HAnsen, H. J., 1922. Crustacés décapodes (Sergestides) provenant des campagnes des yachts "Hirondelle" et "Princesse Alice" (1885-1915). Rés. Camp. scient. Monaco, 64: 1-232, pls. $1-11$.

Heller, C., 1863. Die Crustaceen des südlichen Europa. Crustacea Podophthalmia. Mit einer Übersicht über die horizontale Verbreitung sämmtlicher europäischer Arten: i-xi, 1-336, pls. $1-10$.

Holthuis, L. B. \& E. Gottlieb, 1958. An annotated list of the decapod Crustacea of the Mediterranean coast of Israel with an appendix listing the Decapoda of the eastern Mediterranean. Bull. Res. Counc. Israel, 7B: 1-126.

ILlig, G., 1927. Die Sergestiden der Deutschen Tiefsee-Expedition. Wiss. Ergebn. Valdivia Exped., 23: 279-354, figs. 1-131.

IWASAKI, N., 1990. Pasiphaeid shrimps from the eastern North Atlantic and the Carribbean sea, with the description of a new species of Pasiphaea (Crustacea: Decapoda: Pasiphaeidae).Zool. Meded., Leiden, 63 (15): 187-203.

KASPIRIS, P., 1990. Deep-water Crustacea (Decapoda, Natantia) from the Korinthiakos Gulf, Greece. Ann. Musei Goulandris, 8: 263-267.

Katagan, T., A. Koçatas \& H. Benli, 1988. Note préliminaire sur les Décapodes bathyaux de la $\mathrm{c}$ te Turque de la mer Egée. Rapp. Comm. int. Mer Méditerranée, 31 (2): 23.

Kensley, B., 1971. The family Sergestidae in the waters around southern Africa (Crustacea, Decapoda, Natantia). Ann. South African Mus., 57 (10): 215-264. 
-, 1981. On the zoogeography of southern African decapod Crustacea, with a distributional checklist of the species. Smithsonian Contr. Zool., 338: 1-64.

KöNIG, A., 1895. Die Sergestiden des östlichen Mittelmeeres, gesammelt 1890-93. Berichte der Commission für Erforschung des östlichen Mittelmeeres, 13. Denkschr. Akad. Wiss. Wien, (math.-naturw. K1.) 62: 1-18.

Koukouras, A., K. Dounas, M. Türkay \& E. Voultsiadou-Koukoura, 1992. Decapod crustacean fauna of the Aegean Sea. New information, check list, affinities. Senckenbergiana marit., 22 (3/6): 217-244.

Koukouras, A. \& M. Kattoulas, 1974. Benthic fauna of the Evvoia coast and Evvoia Gulf. III. Natantia (Crustacea: Decapoda). Sci. Ann. Fac. Phys. Mathem. Univ. Thessaloniki, 14: 369-382.

KRøYER, H., 1859. Forsög til en monographisk Fremstilling af Kraebsdyrslaegten Sergestes. Med Bemaerkninger om Dekapodernes Höreredskaber. K. Danske Vidensk. Selsk. Skr., (5) 4: $217-$ 303, pls. 1-5.

Lo Bianco, S., 1903. Le pesche abissali eseguite da F. A. Krupp col yacht "Puritan" nelle adiacenze di Capri ed in altre località del Mediterraneo. Mitt. zool. Stat. Neapel., 16: 109-279, pls. 7-9.

Müller, G. J., 1986. Review of the hitherto recorded species of Crustacea Decapoda from the Bosporus, the Sea of Marmara and the Dardanelles. Cercetari Marine, I.R.C.M. Constanta, 19: 109-130.

Ostroumoff, A., 1896. Comptes-rendus des dragages et du plancton de l'expédition de "Selianik". Bull. Acad. Imp. Sci. St. Petersbourg, 5: 33-92. [In Russian.]

OvChinnikov, I. M., 1966. Circulation in the surface and intermediate layer of the Mediterranean. Oceanology, 6: 48-59.

Pérez Farfante, I. \& B. F. Kensley, 1997. Penaeoid and sergestoid shrimps and prawns of the world. Keys and diagnoses for the families and genera. Mém. Mus. natn. Hist. nat., Paris, 175: 1-233.

Pesta, O., 1918. Die Decapodenfauna der Adria: i-x, 1-500. (Franz Deuticke, Leipzig und Wien).

Pipit One, C. \& M. L. Tumbiolo, 1993. Decapod and stomatopod crustaceans from the trawlable bottoms of the Sicilian channel (central Mediterranean Sea). Crustaceana, 65 (3): 358-364.

Por, F. D. \& C. Dimentman, 1989. The legacy of Tethys: an aquatic biogeography of the Levant. In: H. J. Dumont \& M. J. A. Wergel (eds.), Monographiae biologicae, 63: i-xi, 1-214. (Kluwer Academic Publishers, Dordrecht).

RELINI ORSI, L., 1974. Un ambiente marino di grande interesse naturalistico: i fondi batiali al largo del Promontorio di Portofino. Atti del IV Simp. Nazionale sulla conservazione della Natura, Bari, 1: 141-148.

Relini Orsi, L. \& M. R. CostA, 1975. Segnalazione di Funchalia woodwardi Johnson in Mar Ligure (Crustacea, Decapoda, Penaeidae). Boll. Mus. Ist. Univ. Genova, 43: 33-39.

SARdÀ, F. \& I. PAlo MERA, 1981. Crustáceos Decápodos capturados durante la campaæa "Mediterraneo II" (Marzo, 1977) en el mar catalán. Res. Exp. Cient. (Supl. Inv. Pesq., Barcelona), 9: 143-150.

SennA, A., 1902. Nota sui crostacei. Le esplorazioni abissali nel Mediterraneo del R. Piroscafo "Washington" nel 1881. II. Bull. Soc. Ent. Italiana, 24: 235-367.

SERIDJI, R., 1971. Contribution à l'étude des larves crustacés décapodes en baie d'Alger. Pélagos, 3 (2): 1-107.

Sivertsen, E. \& L. B. Holthuis, 1956. Crustacea Decapoda (the Penaeidae and Stenopodidea excepted). Rep. scient. Res. "Michael Sars" North Atlantic deep-sea Exped. 1910, 5 (12): 1-54.

Smith, S. I., 1882. Report on Crustacea. Part I. Decapoda. Reports on the results of dredging under the supervision of Alexander Agassiz, on the east coast of the United States, during the summer of 1880 , by the U.S. coast survey steamer "Blake", commander J. R. Bartlett, U.S.N., commanding. Bull. Mus. comp. Zool., Harvard, 10: 1-108, pls. 1-16. 
Stephensen, K., 1923. Decapoda - Macrura excluding Sergestidae. Rep. Danish oceanogr. Exped. Mediterranean, 2 (3): 1-85, figs. 1-27.

Sund, O., 1920. Pénéidés et Sténopidés. Rep. scient. Res. "Michael Sars” North Atlantic deep-sea Exped. 1910, 3 (7): 1-36.

Udekem D'ACoz, C. D', 1999. Inventaire et distribution des Crustacés Décapodes de l'Atlantique nord-oriental, de la Méditerranée et des eaux continentales adjacentes au nord de $25^{\circ} \mathrm{N}$. Patrimoines naturels (M.N.H.N./S.P.N.), 40: 1-383. (Muséum National d'Histore Naturelle, Paris).

Vamvak As, C., 1970. Peuplements benthiques des substrats meubles du sud de la mer Egée. Téthys, 2 (1): 89-129.

VAso, A. \& L. GJiknuri, 1993. Decapod crustaceans of the Albanian coast. Crustaceana, 65 (3): 390-407.

VereshchaKA, A. L., 1994. North Atlantic and Caribbean species of Sergia (Crustacea, Decapoda, Sergestidae) and their horizontal and vertical distribution. Steenstrupia, 20 (3): 73-95.

Zariquiey AlvareZ, R., 1946. Crustáceos Decápodos Mediterráneos. Pubbl. Biol. Mediterraneo, Barcelona, 2: 1-183, pls. 1-26.

——, 1957. Decápodos espaæoles XI. La Acanthephyra eximia S. I. Smith, 1884 (Crust. Dec. Nat.) en las costas mediterráneas espaarolas. Inv. Pesq., Barcelona, 10: 3-15.

——, 1968. Crustáceos Decápodos Ibéricos. Inv. Pesq., Barcelona, 32: 1-510. 